\title{
PENENTUAN AMBANG CURAH HUJAN UNTUK MEMPREDIKSI KEJADIAN LONGSOR
}

\section{RAINFALL TRESHOLD DETERMINATION FOR LANDSLIDE EVENTS PREDICTION}

\author{
Rokhmat Hidayat19* , Avidah Amalia Zahro1) \\ Balai Litbang Sabo, Puslitbang SDA - kementerian PUPR \\ *Coresponden author: rokhmathidayat33@gmail.com
}

Diterima: 7 Juni 2018; Direvisi: 10 Januari 2019; Disetujui: 16 April 2020

\begin{abstract}
The mayority of landslide occur due to high rainfall in certain time in areas that have geological potential landslides. Therefore, it is necessary to conduct a research on rainfall characteristics that trigger landslides. So that, it can be used to establish the relationship between rainfall and predicted landslides. This research is aimed to analyze and determine the daily and 3 days rainfall thresholds used for landslides early warning system (LEWS). The case study is placed in both very high risks and high area landslide areas, based on the ground motion maps of the Geological Agency. The analysis was done based on landslide event data from BNPB, as well as TRMM (Tropical Rainfall Measuring Mission) and ECMWF (The European Center for Medium-Range Weather Forecasts) rainfall data. Identification of the rain trigger values from the TRMM rain data was done after collecting landslide incidents at various locations.. The results show that the rainfall threshold values are $61 \mathrm{~mm}$ per day and $91 \mathrm{~mm}$ per 3 days
\end{abstract}

Keywords: Rainfall treshold,landslide prediction, TRMM, ECMWF

\section{ABSTRAK}

Mayoritas tanah longsor terjadi akibat curah hujan yang tinggi dalam kurun waktu tertentu pada daerah yang memiliki sifat geologis berpotensi longsor. Untuk itu perlu dilakukan penelitian mengenai karakteristik hujan yang memicu tanah longsor sehingga dapat digunakan untuk membangun hubungan antara curah hujan dan prediksi terjadinya tanah longsor. Penelitian ini bertujuan untuk menganalisis dan menentukan ambang batas curah hujan harian dan 3 harian yang digunakan untuk peringatan dini terjadinya tanah longsor dengan LEWS (landslide early warning sistem). Daerah yang dimodelkan adalah area yang sangat rawan longsor dan area rawan longsor sesuai peta gerakan tanah dari Badan Geologi. Analisis dilakukan berdasarkan data kejadian longsor dari BNPB, serta data curah hujan TRMM (Tropical Rainfall Measuring Mission) dan ECMWF (The European Centre for Medium-Range Weather Forecasts),. Setelah dilakukan pendataan kejadian longsor pada berbagai lokasi, selanjutnya dilakukan identifikasi nilai hujan pemicu longsor dari data hujan TRMM. Hasil analisis menunjukan ambang hujan yang menjadi pemicu terjadinya tanah longsor yaitu hujan 61 $\mathrm{mm} /$ hari dan $91 \mathrm{~mm} / 3$ hari.

Kata kunci: Ambang hujan, prediksi longsor, TRMM, ECMWF

\section{PENDAHULUAN}

Pada umumnya, bencana longsor terjadi akibat hujan dengan intensitas tinggi yang berlangsung dalam kurun waktu tertentu pada daerah yang berpotensi terjadi bencana longsor. Longsor Jelok Purworejo dipicu oleh hujan $328 \mathrm{~mm} /$ hari yang terjadi hari sebelumnya, sementara longsor Caok Purworejo dipicu hujan $126 \mathrm{~mm} /$ hari (Hidayat dkk., 2017). Karakteristik hujan yang memicu tanah longsor dapat digunakan untuk membangun hubungan antara curah hujan dan tanah longsor. Parameter curah hujan yang paling sering diteliti dalam kaitannya dengan inisiasi tanah longsor meliputi curah hujan kumulatif, curah hujan sebelumnya, dan durasi curah hujan. Berbagai penelitian mengenai peringatan dini longsor dengan penentuan nilai ambang hujan sebagai pemicu longsor telah banyak dilakukan (Gariano dkk, 2015, Brunetti dkk, 2010, Leonarduzzi dkk, 2017; Peres dan Cancelleira, 2013; Caparelli dan Versace, 2011).

Sebagai reaksi cepat atas berbagai kejadian bencana tanah longsor di Indonesia, diperlukan adanya suatu sistem terpadu yang dapat memberikan informasi dan peringatan dini atas kejadian bencana tanah longsor yang sedang berlangsung atau akan berlangsung. Sistem informasi berupa prediksi lokasi rawan terjadi tanah longsor ini diharapkan dapat mempercepat waktu respon, serta mendukung pengambilan keputusan dan upaya penanggulangan yang lebih 
cepat dan tepat. Oleh sebab itu diperlukan mitigasi bencana untuk mengurangi resiko dan kerugian yang mungkin terjadi.

Untuk mengurangi jumlah korban baik jiwa maupun harta benda pada daerah-daerah rawan bencana longsor maka diperlukan adanya suatu sistem peringatan dini dan monitoring untuk seluruh wilayah Indonesia. Pemodelan prediksi banjir di Jakarta (J-FEWS) dilakukan berdasarkan data hujan yang terkait (Loenen, 2014). Belum adanya suatu sistem terpadu yang dapat memberikan peringatan dini akan bencana sedimen untuk wilayah Indonesia merupakan tantangan yang harus dipecahkan dengan inovasi teknologi yang sudah ada. Inovasi ini diharapkan dapat memberikan peringatan kepada masyarakat akan potensi bencana yang akan terjadi dan juga kepada lembaga-lembaga yang berkaitan dengan penanganan bencana seperti Badan Nasional Penanggulangan Bencana (BNPB) dan Badan Penanggulangan Bencana Daerah (BPBD). Pemodelan tanah longsor secara makro dilakukan dengan program LEWS yang sudah dimodifikasi. LEWS pada awalnya software untuk pemodelan banjir yang dikembangkan oleh DELTARES Belanda, kemudian dimofikasi untuk pemodelan tanah longsor.

Kondisi tatanan geologis seperti pola patahan batuan, perlapisan batuan, ketebalan tanah lapuk, kemiringan curam, kandungan air tinggi dan getaran gempa dapat berpengaruh pada gerakan tanah (Kementerian Lingkungan Hidup, 2007). Sifat geologis tersebut yang disertai dengan curah hujan tinggi menjadikan rawan terjadinya longsoran (Parwati, 2008). Setiap daerah di Indonesia memiliki karakteristik tanah yang berbeda, berdasarkan perbedaan tersebut Badan geologi telah mengklasifikasi wilayah di Indonesia berdasar tingkat kerawanan longsor. Ketika informasi tentang tanah longsor dan hujan tersedia, plot data dapat dilakukan dan garis batasan dapat digunakan untuk menentukan batas awal terjadinya longsor pada lereng (Muntohar, 2009).

Di era global ini masyarakat membutuhkan informasi yang tepat, cepat dan akurat. Salah satu sarana yang berperan penting dalam hal-hal yang berhubungan dengan informasi yaitu teknologi. Teknologi dapat dimanfaatkan untuk menyelesaikan permasalahan dan meningkatkan kinerja. Teknologi semakin berkembang pesat dalam berbagai aspek kehidupan seperti sosial, budaya, pendidikan, dan lingkungan. Pengembangan teknologi untuk prediksi potensi terjadinya longsor sangat dibutuhkan dalam bidang lingkungan dan diharapkan dapat mendeteksi gejala-gejala alamiah yang muncul berkaitan dengan bahaya tanah longsor sedini mungkin untuk meminimalkan jatuhnya korban jiwa (Sipayung, 2014).

Sebenarnya longsor merupakan bencana alam yang dapat diramalkan, karena kedatangannya berhubungan erat dengan besar curah hujan (Kementerian Lingkungan Hidup, 2007). Pada kebanyakan peristiwa longsor, keruntuhan lereng selalu terjadi ketika musim penghujan dengan curah hujan yang sangat tinggi (Muntohar, 2009). Secara alamiah sudah terlihat apabila suatu kawasan yang rawan longsor memiliki tatanan geologis yang tersendiri. Batuan yang mudah disintegrasi, pola patahan batuan, perlapisan batuan, ketebalan tanah lapuk, kemiringan curam, kandungan air tinggi dan getaran gempa merupakan sifat geologis yang mempengaruhi kejadian longsoran (Kementerian Lingkungan Hidup, 2007). Perubahan dan proses alam tersebut tidak perlu dirisaukan tetapi harus disikapi secara adaptif, sehingga mampu melakukan tindakan bijak, karena manusia dapat juga sebagai faktor pemacu proses longsoran, misalnya secara sengaja melakukan penambahan beban, penambahan kadar air, penambahan sudut lereng (Paimin dkk., 2009; Kementerian Lingkungan Hidup, 2007).

Karakterisasi curah hujan yang memicu tanah longsor telah digunakan untuk membangun hubungan antara curah hujan dan tanah longsor di berbagai belahan dunia termasuk tanah longsor yang terjadi di Indonesia (Hasnawir, 2012). Penelitian mengenai peringatan dini longsor berbasis intensitas hujan juga telah dilakukan di daerah Calabria, Italia Selatan (De Luca dan Versace, 2017; Peres dkk., 2017).

Dari tahun ke tahun jumlah kejadian bencana alam tanah longsor relatif statis atau bahkan meningkat. Jumlah kejadian longsor yang tercatat oleh BNPB dari bulan Januari hingga Mei 2017 sebanyak 367 kejadian. Peristiwa longsor dapat berdampak pada kerugian jiwa dan material serta kerusakan lingkungan, maka untuk mengurangi kerugian jiwa diperlukan sistem peringatan dini. Salah satunya yaitu dengan metode penerapan ambang hujan di dalam sistem tersebut (Muntohar, 2009).

Penggunaan sistem peringatan dini berbasis ambang hujan empiris telah banyak digunakan pada berbagai bidang. Hal penting dari sistem ini adalah tersedianya komponen terkait dengan prakiraan curah hujan (Satya dkk., 2014). DelftFEWS merupakan teknologi penanganan data terbuka yang awalnya dikembangkan sebagai peramalan dan sistem peringatan hidrologi yang disesuaikan dengan kebutuhan spesifik suatu organisasi perorangan. Delft-FEWS dikembangkan oleh Deltares Belanda, yaitu lembaga independen untuk penelitian terapan di bidang air, di bawah permukaan dan infrastruktur. Dua kali setahun 
versi baru Delft-FEWS dilepaskan, berisi fitur baru dan perbaikan kesalahan.

Menurut NASDA (National Space Development of Japan, 2001), data hujan TRMM adalah data precipitasi (hujan) yang didapat dari satelit meteorologi TRMM. Satelit TRMM tersebut merupakan hasil kerjasama dua badan antariksa nasional, yaitu Amerika Serikat (NASA : National Aeronautics and Space Administration) dan di Jepang NASDA sekarang berubah menjadi JAXA Uapan Aerospace Exploration Agency). Satelit TRMM diluncurkan pada tanggal 27 November 1997. Data hujan TRMM terutama mengamati struktur hujan, intensitas, dan distribusi di wilayah tropis dan subtropis.

Data hujan yang dihasilkan oleh TRMM memiliki tipe dan bentuk yang cukup beragam yang dimulai dari level 1 sampai level 3. Level 1 merupakan data yang masih dalam bentuk mentah dan telah dikalibrasi dan dikoreksi geometrik, Level 2 merupakan data yang telah memiliki gambaran paramater geofisik hujan pada resolusi spasial yang sama akan tetapi masih dalam kondisi asli keadaan hujan saat satelit tersebut melewati daerah yang direkam, sedangkan level 3 merupakan data yang telah memiliki nilai-nilai hujan, khususnya kondisi hujan bulanan yang merupakan penggabungan dari kondisi hujan dari level 2. Untuk mendapatkan data hujan dalam bentuk milimeter ( $\mathrm{mm}$ ) sebaiknya menggunakan level 3 , dengan resolusi spasial $0,25^{\circ}$ x $0,25^{\circ}$ dan resolusi temporal setiap 3 jam.

BMKG memiliki akses data untuk satelit TRMM di mana dari satelit ini didapat data estimasi curah hujan untuk titik mana saja yang diperlukan pada seluruh wilayah di Indonesia. Hal ini tentu sangat membantu bagi pihakpihak yang membutuhkan data hujan. Data satelit TRMM dapat dijadikan data alternatif dalam menggantikan data curah hujan observasi yang biasanya datanya terbatas dan tidak selalu kontinyu. Data TRMM memiliki kelebihan seperti dapat diunduh secara gratis, praktis dan selalu update. Selain data hujan TRMM juga diperlukan data prediksi hujan dari data satelit ECMWF yang merupakan prakiraan hujan selama 10 hari ke depan. Gabungan data hujan TRMM dan data prediksi hujan digunakan untuk prediksi kejadian longsor.

Berdasarkan permasalahan yang telah dipaparkan, maka perlu ditentukan nilai ambang hujan pemicu longsor. Nilai ambang curah hujan ditumpangsusun dengan peta kerentanan longsor akan menghasilkan informasi prediksi lokasi rawan terjadi longsor di wilayah Indonesia.

Tujuan dari penelitian ini adalah untuk menganalisis curah hujan dan menentukan ambang curah hujan pemicu terjadinya longsor. Ambang hujan yang ditentukan yaitu ambang hujan harian dan ambang hujan kumulatif 3 harian. Nilai ambang hujan ini berfungsi untuk peringatan dini terjadinya bencana tanah longsor.

\section{METODOLOGI}

Secara umum bagan alir metode pemodelan prediksi longsor secara makro dapat dilihat pada Gambar 1, yaitu:

1 Melakukan pendataan kejadian longsor pada berbagai lokasi. Data kejadian longsor dari tanggal 1 Januari-27 November 2017 yang diperoleh dari Badan Nasional Penanggulangan Bencana (BNPB), maupun bersumber dari media massa.

2 Menghitung data hujan pemicu longsor pada masing-masing lokasi kejadian longsor, dengan data curah hujan TRMM. Data curah hujan TRMM digunakan untuk mengetahui data curah hujan yang turun di daerah terjadinya longsor. Data tersebut didapatkan dari situs trmmopen.gsfc.nasa.gov milik NASA. kemudian data tersebut diolah dalam bentuk tabulasi.

3 Data curah hujan pemicu longsor pada masing-masing lokasi diplot dalam grafik hujan kumulatif. Berdasarkan data kejadian longsor tersebut dilakukan pemeriksaan hujan pemicu longsor, kemudian diplot pada grafik. Dari grafik tersebut dapat diamati dan dianalisis untuk menentukan nilai ambang hujan pemicu longsor, baik hujan harian maupun hujan kumulatif 3 harian. Nilai ambang hujan diperoleh dari nilai tengah curah hujan pemicu longsor.

4 Data peramalan hujan yang melebihi nilai kritis longsor inilah yang nantinya akan digunakan juga dalam sistem peringatan dini longsor. Perhitungan simulasi prediksi gerakan tanah dilakukan pada zona oranye (rawan longsor) dan zona merah (sangat rawan longsor), karena mayoritas longsor terjadi pada kedua zona ini. Bila pada zona tersebut terjadi hujan deras yang melewati ambang batas maka akan rawan terjadi 


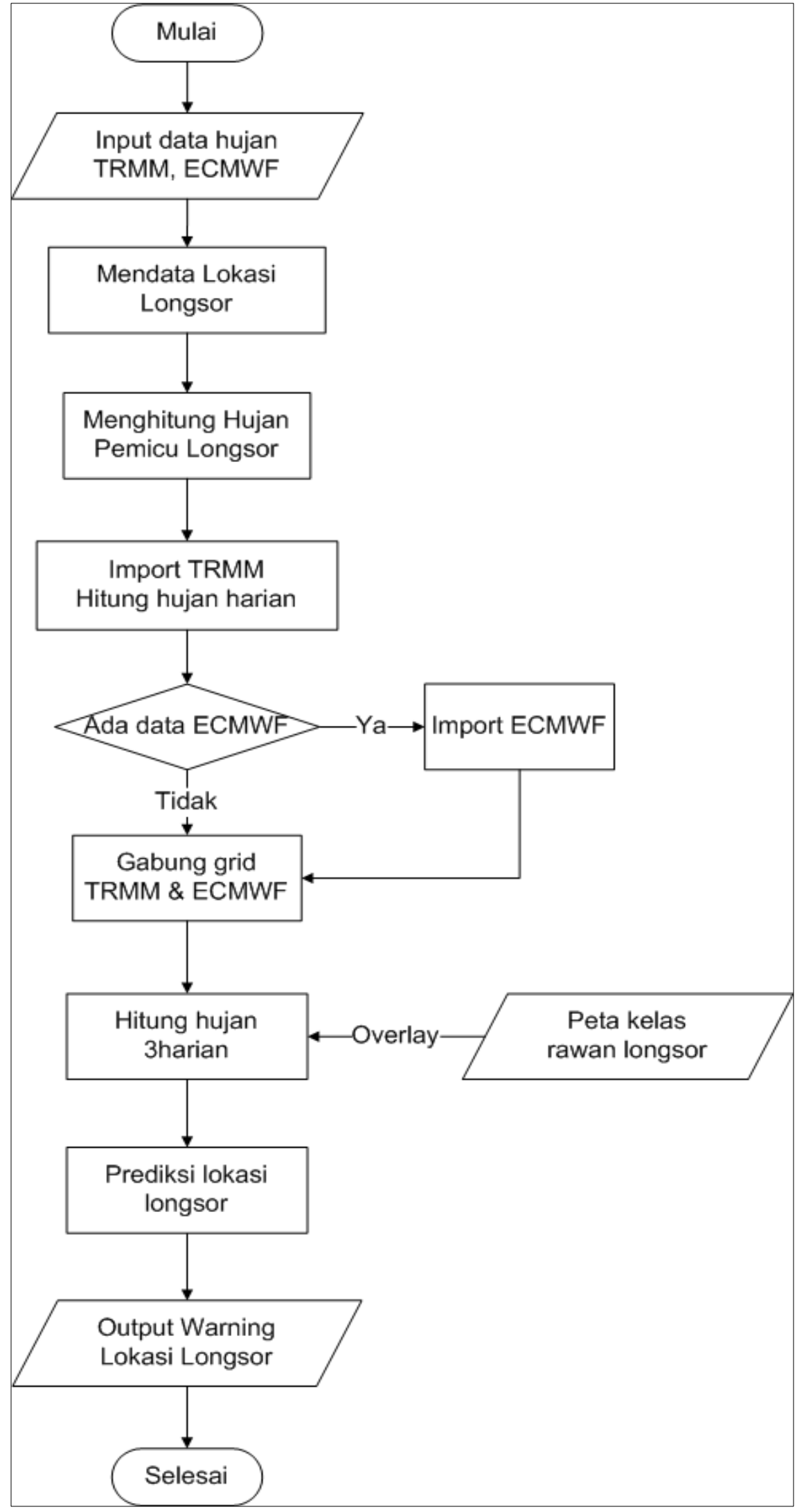

Gambar 1 Bagan Alir Metode Pemodelan Prediksi Longsor Secara Makro 
5 longsor, sehingga akan muncul peringatan dini longsor. Penentuan ambang batas tersebut yaitu:

a Apabila hujan harian dan hujan 3 harian lebih besar dari ambang hujan, maka hasil simulasi memberikan tanda peringatan tanda seru merah (kedua syarat terpenuhi).

b Apabila hujan harian atau hujan 3 harian lebih besar dari ambang hujan masingmasing, maka hasil simulasi memberikan tanda peringatan tanda seru kuning (salah satu syarat terpenuhi).

c Apabila hujan harian dan hujan 3 harian tidak lebih besar dari ambang hujan yang ditentukan masing-masingnya, maka hasil simulasi memberikan tanda bulat hijau (kedua syarat tidak terpenuhi).

6 Menganalisis zona warna pada peta kerentanan longsor. Peta tingkat kerawanan gerakan tanah Indonesia diperoleh dari Badan Geologi yang telah dilakukan pembobotan dan dikelompokkan menjadi 4 zona sesuai dengan tingkat kerentanan longsor. Pada peta kerawanan longsor terdapat 4 zona warna, yaitu zona hijau, zona biru, zona oranye, dan zona merah, seperti yang ditunjukkan pada Gambar 2.

7 Data hujan didapatkan dari BMKG, merupakan data hujan yang telah dijadikan di dalam satu sistem LEWS. Interpolasi hujan grid ke peta gerakan tanah, pada dasarnya merupakan konversi data hujan dari bentuk grid menjadi scalar yang diwujudkan dengan ikon/bullet. Untuk mensimulasikan longsor pada program LEWS diperlukan beberapa konfigurasi yang dilakukan pada program LEWS yaitu pengaturan lokasi peta kerawanan longsor, peta prediksi hujan, dan ambang hujan.. File yang digunakan yaitu file peta kerawanan longsor, file peta hujan, dan file ambang hujan.

8 Laporan peringatan dini gerakan tanah berupa gambar peta Indonesia beserta tanda peramalan daerah rawan longsor. Selain itu, terdapat pula tabel keterangan dari gambar peta tersebut. Laporan yang dihasilkan memiliki tipe file html yang dapat digunakan untuk mempublikasikan informasi peramalan peringatan dini longsor di website Balai Litbang Sabo.

\section{HASIL DAN PEMBAHASAN}

Pada Tabel 1 dapat dilihat data kejadian longsor beserta hujan pemicunya. Prediksi lokasi rawan terjadi longsor dengan LEWS membutuhkan data hujan baik data hujan yang sudah terjadi maupun hujan prediksi. Data hujan harian didapatkan dari mengkonversi data hujan per 3 jam menjadi data hujan 1 hari. Untuk menghasilkan peramalan gerakan tanah, LEWS menggunakan data hujan TRMM sebagai data hujan yang telah terjadi dan ECMWF sebagai data hujan prediksi ke depan.

Pada program LEWS data yang digunakan yaitu data hujan harian dan hujan kumulatif 3 harian sebagai hujan pemicu longsor. Dalam penelitian ini juga digunakan hujan kumulatif 3 harian karena pada beberapa longsor diawali dengan proses penjenuhan (peresapan), sehingga data hujan kumulatif 3 harian diperlukan untuk peramalan gerakan tanah. Data hujan 3 harian didapatkan dari kumulatif hujan harian. Data hujan selanjutnya ditumpang susun (overlay) dengan peta tingkat rawan longsor.

Penentuan ambang hujan harian dan hujan kumulatif tiga harian pemicu longsor didasarkan pada data kejadian longsor dan hujan pemicu longsor. Pertama dilakukan dengan pendataan lokasi kejadian longsor. Tiap lokasi longsor dicatat lokasi dan tanggal kejadian. Dari tiap lokasi kejadian longsor tersebut, selanjutnya dihitung hujan pemicu longsor, baik hujan harian maupun hujan kumulatif 3 harian, dapat dilihat pada Tabel 1. Dari data tersebut selanjutnya dihitung nilai tengah hujan pemicu longsor, baik hujan harian maupun hujan 3 harian (Gambar 3). Dari Gambar 3 dapat kita tentukan ambang hujan pemicu longsor, yaitu untuk hujan harian sebesar $61 \mathrm{~mm}$, sedangkan kumulatif tiga harian sebesar $91 \mathrm{~mm}$.

Nilai indeks ambang curah hujan yang berpotensi menyebabkan longsor diperoleh berdasarkan data kejadian longsor, kemudian dihitung hujan pemicu longsor baik harian maupun kumulatif 3 harian. Peta kerawanan longsor dibuat berdasarkan nilai curah hujan, kondisi geologi (jenis batuan dan pola patahan batuan), perlapisan batuan, ketebalan tanah lapuk, kemiringan curam, penggunaan lahan, dan getaran gempa. Peta kerawanan longsor wilayah Indonesia yang digunakan untuk pemodelan prediksi terjadinya longsor yaitu pada zona oranye (daerah rawan) dan zona merah (daerah sangat rawan), mengingat mayoritas kejadian longsor berada pada dua zona tersebut. Untuk daerah dataran bila terjadi hujan deras, maka hal itu tidak mengakibatkan longsor melainkan banjir. 


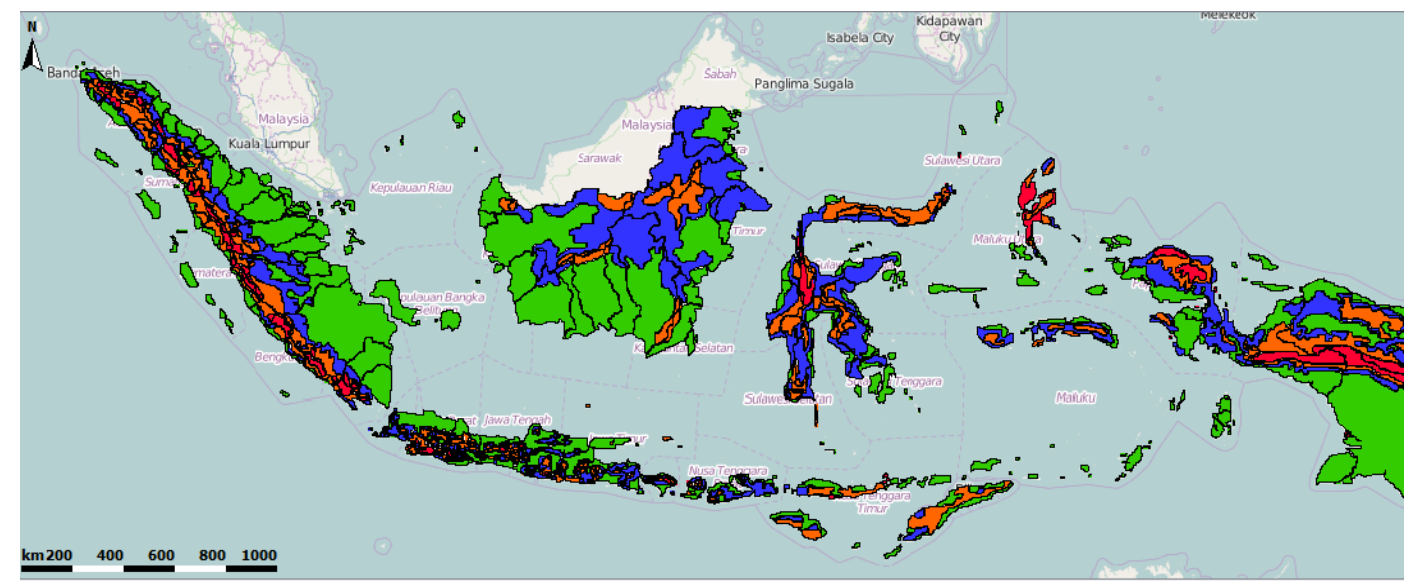

Gambar 2 Peta Tingkat Rawan Longsor Indonesia (Badan Geologi, 2014)

Tabel 1 Hasil Verifikasi Hujan Harian dan Tiga Harian Pemicu Longsor Pada Beberapa Lokasi

\begin{tabular}{|c|c|c|c|c|c|}
\hline NO & PROVINSI & KABUPATEN & TGL & Hujan harian (mm) & Hujan 3 harian $(\mathrm{mm})$ \\
\hline 1 & Jawa Tengah & Cilacap & 17-Mar-17 & 55,32 & 61,2 \\
\hline 2 & Jawa Timur & Nganjuk & 19-Mar-17 & 24,72 & 53,94 \\
\hline 3 & Di Yogyakarta & Sleman & 26-Mar-17 & 103,23 & 118,02 \\
\hline 4 & Jawa Tengah & Banyumas & 6-Apr-17 & 31,14 & 92,61 \\
\hline 5 & Jawa Tengah & Temanggung & 6-Apr-17 & 55,32 & 98,4 \\
\hline 6 & Jawa Tengah & Magelang & 6-Apr-17 & 56,04 & 117,6 \\
\hline 7 & Jawa Timur & Kediri & 6-Apr-17 & 56,04 & 109,61 \\
\hline 8 & Jawa Tengah & Magelang & 6-Apr-17 & 70 & 117,6 \\
\hline 9 & Jawa Tengah & Banyumas & 7-Apr-17 & 58,62 & 86,07 \\
\hline 10 & Jawa Tengah & Magelang & 7-Apr-17 & 50,52 & 101,13 \\
\hline 11 & Jawa Barat & Tasikmalaya & 8-Apr-17 & 22,68 & 112,74 \\
\hline 12 & Jawa Timur & Situbondo & 8-Apr-17 & 27,66 & 90,18 \\
\hline 13 & Jawa Barat & Garut & 9-Apr-17 & 46,62 & 77,25 \\
\hline 14 & Jawa Barat & Sukabumi & 11-Apr-17 & 59,94 & 85,53 \\
\hline 15 & Jawa Tengah & Magelang & 22-Apr-17 & 98,34 & 103,02 \\
\hline 16 & Jawa Timur & Ponorogo & 23-Apr-17 & 51,9 & 83,49 \\
\hline 17 & Jawa Tengah & Wonogiri & 23-Apr-17 & 61,41 & 108,55 \\
\hline 18 & Jawa Timur & Ponorogo & 25-Apr-17 & 34,68 & 108,07 \\
\hline 19 & Jawa Timur & Ponorogo & 4-May-17 & 46,2 & 108,07 \\
\hline 20 & Jawa Tengah & Karanganyar & 29-May-17 & 56,76 & 63,81 \\
\hline 21 & Sulawesi Selatan & Tana Toraja & 6-Jun-17 & 83,34 & 97,56 \\
\hline 22 & Sulawesi Tenggara & Muna & 20-Jun-17 & 117,21 & 117,21 \\
\hline 23 & Sulawesi Tenggara & Muna & 20-Jun-17 & 110,46 & 152,85 \\
\hline 24 & Maluku Utara & Pulau Taliabu & 16-Aug-17 & 82,41 & 85,53 \\
\hline 25 & Jawa Barat & Tasikmalaya & 7-Oct-17 & 57,78 & 89,55 \\
\hline 26 & Jawa Tengah & Semarang & $28-O c t-17$ & 57,81 & 71,01 \\
\hline 27 & Jawa Tengah & Purworejo & $28-O c t-17$ & 100,86 & 141,87 \\
\hline 29 & Jawa Tengah & Magelang & 10-Nov-17 & 68,13 & 100,05 \\
\hline 30 & Jawa Tengah & Semarang & 12-Nov-17 & 101,04 & 112,98 \\
\hline
\end{tabular}

Sumber: Hasi survey, media massa, data BNPB 2017 (https://bnpb.cloud/dibi/) 
Contoh hasil pemodelan lokasi rawan longsor dengan LEWS pada tanggal 12-14 Desember 2017 dapat dilihat pada Gambar 4, dan tabel lokasi longsor dapat dilihat pada Tabel 2. Dari Gambar 4 dapat dilihat bahwa terdapat beberapa lokasi yang diprediksi rawan terjadi longsor maupun sangat rawan terjadi longsor. Terdapat dua jenis tanda peringatan yaitu rawan terjadi longsor dan sangat rawan terjadi longsor. Untuk daerah yang mempunyai tingkat kerawanan gerakan tanah tinggi, maka batas hujan kumulatif 3 harian dan hujan harian yang digunakan adalah $91 \mathrm{~mm}$ dan $61 \mathrm{~mm}$. Apabila batas hujan terpenuhi dua-duanya, hujan harian $61 \mathrm{~mm}$ dan hujan kumulatif 3 harian $>91 \mathrm{~mm}$, maka muncul peringatan sangat rawan (pada peta prediksi muncul tanda ()). Apabila batas hujan terpenuhi salah satu saja, misal hujan harian $>61 \mathrm{~mm}$ saja atau hujan kumulatif 3harian > 91mm saja, maka muncul peringatan rawan terjadi longsor (pada peta prediksi muncul tanda !). Hasil pemodelan lokasi rawan terjadi longsor dengan LEWS sudah dipublikasikan lewat situs longsor Balai Litbang Sabo, melalui sabo.pusairpu.go.id pada menu LEWS.

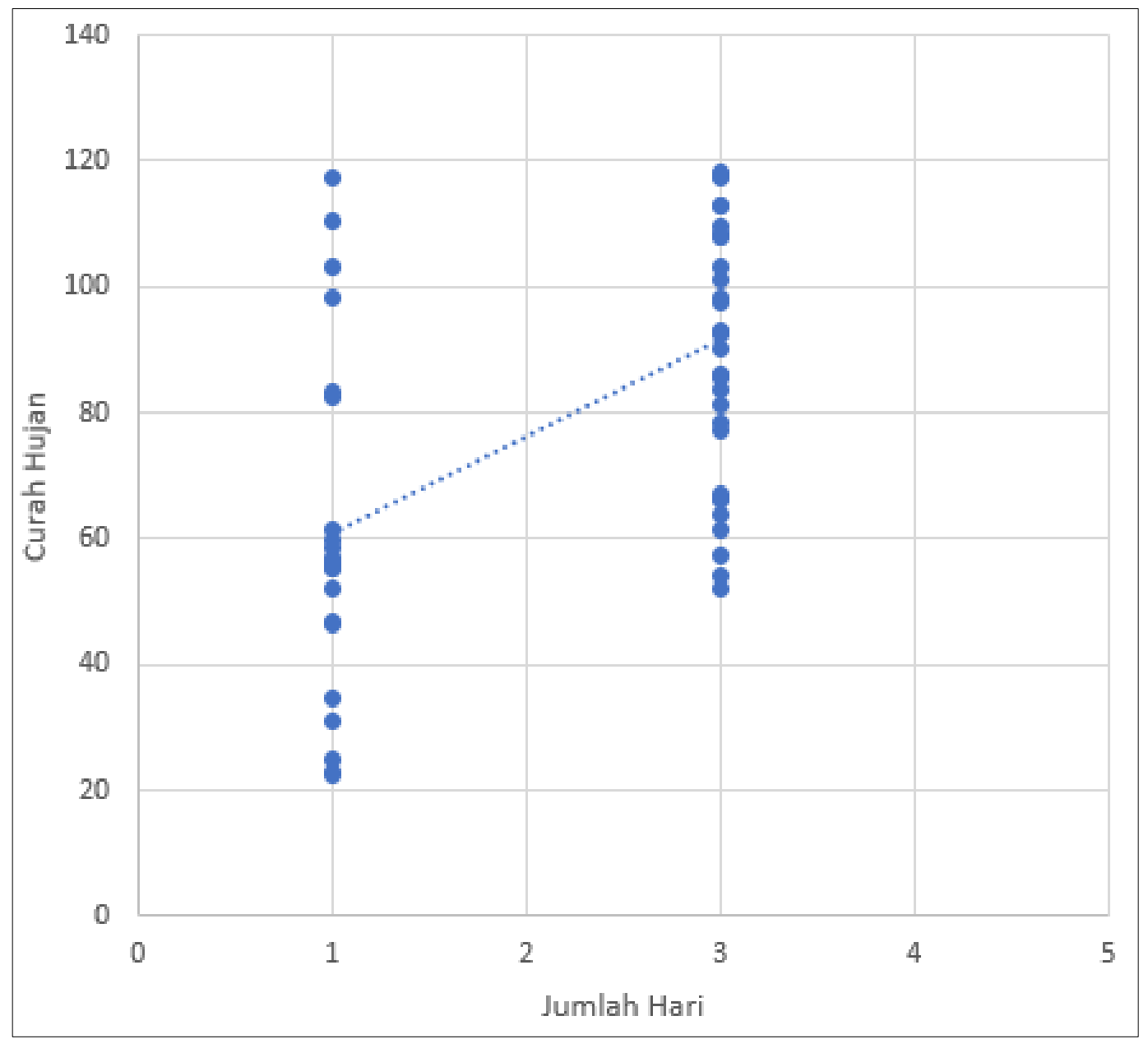

Gambar 3 Penentuan Ambang Hujan Pemicu Longsor Berdasar Data Kejadian Longsor, Untuk Hujan Harian 61mm, dan Hujan Kumulatif Tiga Harian 91mm 

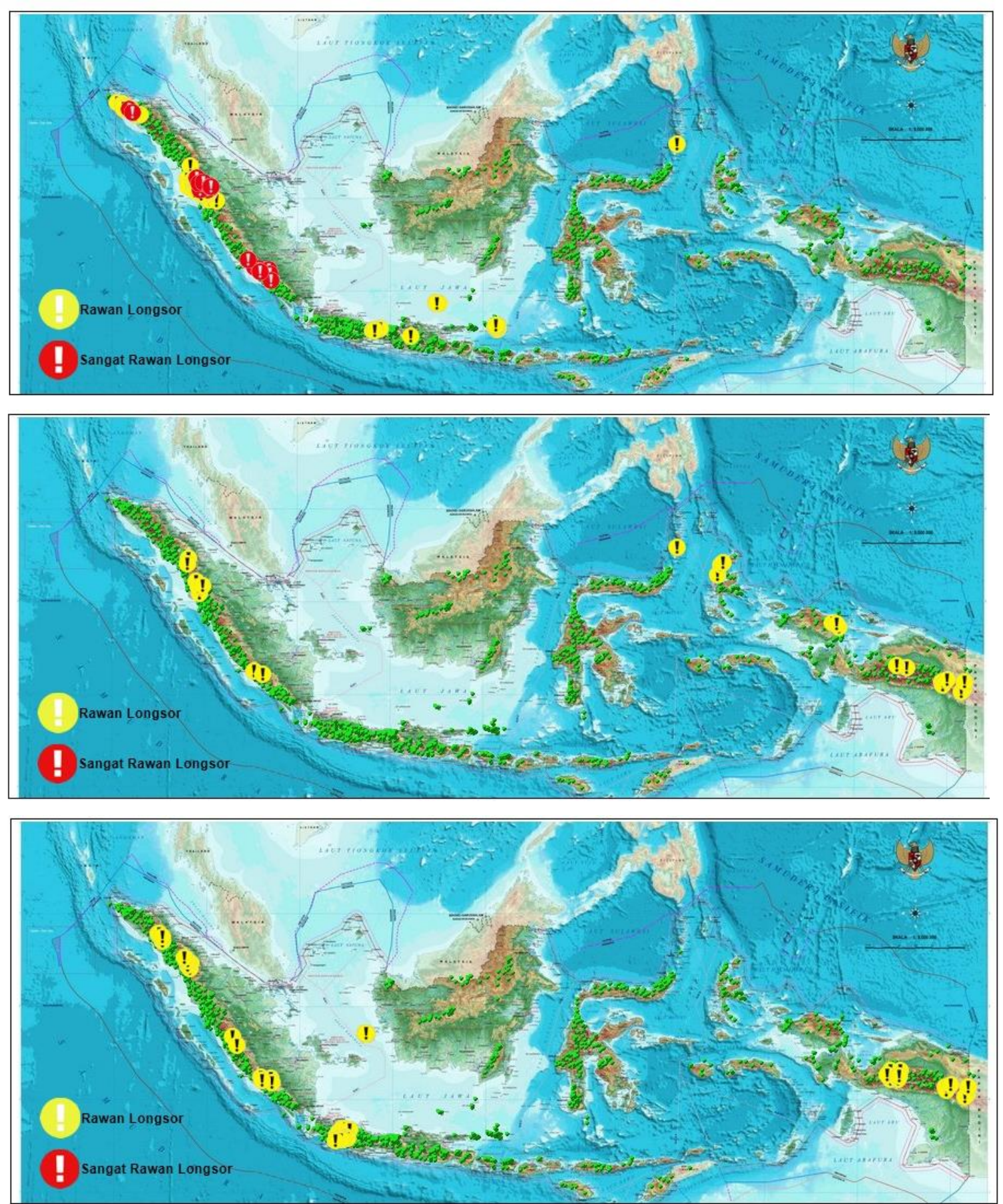

Gambar 4 Hasil Simulasi Longsor Tanggal 12-14 Desember 2017, atas ke bawah. Ambang Hujan Harian $61 \mathrm{~mm} /$ hari dan Hujan 3 Harian $91 \mathrm{~mm} / 3$ hari.

Program ini pada prinsipnya adalah tumpang susun peta tingkat kerawanan longsor dari Badan Geologi dengan peta prediksi curah hujan dari Badan Meteorologi, Klimatologi dan Geofisika (BMKG) Data curah hujan spasial dan temporal didapatkan dari satelit dan BMKG disimpan dalam database untuk kemudian secara automatis diinputkan ke dalam model. Program Delft-LEWS kemudian akan memproses setiap nilai gerakan tanah akan mempunyai nilai batas hujan tersendiri. Data hujan yang digunakan untuk prakiraan bencana longsor yaitu data hujan TRMM dan data hujan ECMWF. 
Tabel 2 Wilayah Sungai Yang Rawan Terjadi Longsor Tanggal 12-14 Desember 2017

\begin{tabular}{|c|c|c|c|c|}
\hline Wilayah Sungai & Kabupaten & Status Hari Ini & Status Besok & Status Lusa \\
\hline WS ALAS-SINGKIL & ACEH TENGGARA & & & Rawan Longsor \\
\hline WS ALAS-SINGKIL & LANGKAT & & & Rawan Longsor \\
\hline WS BARUMUN-KUALUH & LABUHANBATU UTARA & & Rawan Longsor & Rawan Longsor \\
\hline WS BARUMUN-KUALUH & PADANG LAWAS & Rawan Longsor & & \\
\hline WS BARUMUN-KUALUH & PADANG LAWAS & Rawan Longsor & & \\
\hline WS BARUMUN-KUALUH & PADANG LAWAS UTARA & Rawan Longsor & & \\
\hline WS BARUMUN-KUALUH & TAPANUU SELATAN & & Rawan Longsor & Rawan Longsor \\
\hline WS BARUMUN-KUALUH & TAPANULI UTARA & & & Rawan Longsor \\
\hline WS BARUMUN-KUALUH & TOBA SAMOSIR & & & Rawan Longsor \\
\hline WS BARUMUN-KUALUH & TOBA SAMOSIR & & & Rawan Longsor \\
\hline WS BATANG ANGKOLA-BATANG GADIS & MANDAILING NATAL & Rawan Longsor & & \\
\hline WS BATANG ANGKOLA-BATANG GADIS & MANDAILING NATAL & Rawan Longsor & & \\
\hline WS BATANG ANGKOLA-BATANG GADIS & PASAMAN & Rawan Longsor & & \\
\hline WS BATANG ANGKOLA-BATANG GADIS & PASAMAN & Rawan Longsor & & \\
\hline WS BATANG ANGKOLA-BATANG GADIS & PASAMAN BARAT & Rawan Longsor & & \\
\hline WS BATANG NATAL-BATANG BATAHAN & MANDAILING NATAL & Rawan Longsor & & \\
\hline WS BATANG NATAL-BATANG BATAHAN & PASAMAN BARAT & Rawan Longsor & & \\
\hline WS BATANGHARI & BUNGO & & & Rawan Longsor \\
\hline WS BATANGHARI & MERANGIN & & & Rawan Longsor \\
\hline WS BENGAWAN SOLO & NGAW & Rawan Longsor & & \\
\hline $\begin{array}{l}\text { WS CIDANAU-CIUJUNG-CIDURIAN-CISADANE-CILIWUNG- } \\
\text { CIT* }^{*}\end{array}$ & BANDUNG & & & Rawan Longsor \\
\hline $\begin{array}{l}\text { WS CIDANAU-CIUJUNG-CIDURIAN-CISADANE-CILIWUNG- } \\
\text { CIT* }^{*}\end{array}$ & BANDUNG & & & Rawan Longsor \\
\hline $\begin{array}{l}\text { WS CIDANAU-CIUJUNG-CIDURIAN-CISADANE-CILIWUNG- } \\
\qquad \text { CIT }^{*}\end{array}$ & BANDUNG & & & Rawan Longsor \\
\hline $\begin{array}{l}\text { WS CIDANAU-CIUJUNG-CIDURIAN-CISADANE-CILIWUNG- } \\
\text { CIT }^{*}\end{array}$ & BANDUNG BARAT & & & Rawan Longsor \\
\hline $\begin{array}{l}\text { WS CIDANAU-CIUJUNG-CIDURIAN-CISADANE-CILIWUNG- } \\
\text { CIT" }\end{array}$ & BANDUNG BARAT & & & Rawan Longsor \\
\hline $\begin{array}{l}\text { WS CIDANAU-CIUJUNG-CIDURIAN-CISADANE-CILIWUNG- } \\
\qquad \text { CIT* }^{*}\end{array}$ & BANDUNG BARAT & & & Rawan Longsor \\
\hline $\begin{array}{l}\text { WS CIDANAU-CIUJUNG-CIDURIAN-CISADANE-CILIWUNG- } \\
\text { CIT* }^{*}\end{array}$ & CIANJUR & & & Rawan Longsor \\
\hline $\begin{array}{l}\text { WS CIDANAU-CIUJUNG-CIDURIAN-CISADANE-CILIWUNG- } \\
\text { CIT" }\end{array}$ & CIANJUR & & & Rawan Longsor \\
\hline
\end{tabular}

Akurasi ketelitian prediksi lokasi rawan terjadi longsor sangat bergantung pada akurasi prediksi hujan. Apabila dari BMKG memprediksi suatu lokasi terjadi hujan maka hal ini akan berpengaruh terhadap hasil prediksi longsor, demikian juga sebaliknya. Akurasi prediksi lokasi rawan terjadi longsor sangat tergantung pada akurasi prediksi cuaca. Beberapa kejadian longsor yang sesuai prediksi adalah longsor Pacitan 16 Oktober 2017 dan longsor Brebes 22 Februari 2018. Sistem peringatan dini longsor berbasis satelit cuaca mempunyai keunggulan antara lain dapat menjangkau area yang luas (seluruh Indonesia), dapat memprediksi hujan hinggga empat hari ke depan, dan kesempatan (waktu) yang cukup untuk tindakan mitigasi bagi warga yang rawan terkena bencana lebih longgar.

\section{KESIMPULAN}

Usaha untuk memprediksi kejadian longsor yaitu dengan menentukan besaran nilai ambang hujan pemicu longsor baik hujan harian maupun kumulatif tiga harian,. Untuk menentukan nilai ambang pemicu terjadinya longsor dilakukan dengan pendataan kejadian longsor, dan mengidentifikasi hujan pemicu longsor masingmasing kejadian, baik hujan harian maupun hujan 3 harian. Berdasarkan hasil pendataan dapat diketahui, nilai ambang hujan pemicu terjadinya tanah longsor yaitu curah hujan $61 \mathrm{~mm} /$ hari dan $91 \mathrm{~mm} / 3$ hari. Prediksi longsor dilakukan dengan membuat tumpangsusun antara peta rawan longsor dari Badan Geologi dengan peta hujan. Daerah dengan tingkat rawan longsor tinggi bila terjadi hujan yang melewati ambang hujan maka diprediksi terjadi rawan longsor. Dengan adanya peringatan dini longsor ini dapat digunakan untuk antisipasi kejadian longsor sehingga korban dan kerugian yang diakibatkan longsor dapat diminimalisir. Akurasi ketelitian prediksi lokasi rawan terjadi longsor sangat bergantung pada akurasi prediksi hujan. Perlu dilakukan analisis di titik lokasi longsor yang lain, sehingga semakin banyak data yang digunakan akan menghasilkan prediksi yang lebih akurat curah hujan pemicu longsor di Indonesia. Nilai ambang hujan pemicu longsor sangat tergantung pada kondisi tingkat kerentanan daerah yang bersangkutan, sehingga perlu dilakukan penelitian lebih lanjut mengenai 
ambang hujan untuk masing masing zona atau disesuaikan dengan kerentanan suatu daerah.

\section{DAFTAR PUSTAKA}

Badan Geologi, (2014), Peta tingkat kerawanan gerakan tanah di Indonesia, Badang Geologi DESDM, Bandung

Brunetti, M. T., Peruccacci, S., Rossi, M., Luciani, S., Valigi, D., dan Guzzetti, F. (2010). Rainfall thresholds for the possible occurrence of landslides in Italy, Nat. Hazards Earth Syst. Sci., 10:447-458 https://doi.org/10.5194/nhess10-447-2010.

Capparelli, G. \& Versace, P. (2011), FLaIR and SUSHI: Two mathematical models for Early Warning Sistems for rainfall induced landslides, Landslides, 8: 67-79 https://doi.org/10.1007/s10346-

De Luca D. L., dan Versace P., (2017), Diversity of Rainfall Thresholds for early warning of hydrogeological disasters, Advance in Geoscience., 44:53-60 https://doi.org/10.5194/ adgeo-44-53-2017

Gariano, S. L., Brunetti, M. T., lovine, G., Melillo, M., Peruccacci, S., Terranova, O., Vennari, C., \& Guzzetti, F. (2015). Calibration and validation of rainfall thresholds for shallow landslide forecasting in Sicily, southern Italy. Geomorphology, 228:653-665.

https://doi.org/10.1016/j.geomorph.2014. 10.019 .

Hasnawir (2012). Ambang Batas Curah Hujan Untuk Bencana Sedimen Di Kaldera Bawakaraeng, Sulawesi Selatan. Jurnal Penanggulangan Bencana, Vol.3(1):14-24.

Hidayat, R., Sutanto, S.J., \& Munir, M. D., (2017). Kondisi Geologi Dan Pola Hujan Sebagai Pemicu Longsor Di Jawa Tengah Bagian Selatan Pada Juni 2016. Jurnal Teknik Hidraulik, Vol. 7 No.2:147-146

https://bnpb.cloud/dibi/ data kejadian longsor di Indonesia tahun 2017

Kementerian Lingkungan Hidup (2007). Analisis Potensi Bencana Alam di Papua dan Maluku. Kementerian Negara Lingkungan Hidup. Laporan Akhir.

http://geospasial.menlh.go.id/assets/Analisis/ AnalisisPotensiBencanaAlam-KLH.pdf.

Leonarduzzi, E., Molnar, P., dan McArdell, B. W., (2017), Predictive performance of rainfall thresholds for shallow landslides in Switzerland from gridded daily data, Water Resour. Res., 53: 6612-6625,

https://doi.org/10.1002/2017WR021044
Loenen, A.V. (2014). Implementation of a Flood Management Information System in Jakarta. Disajikan pada 13th International Conference on Urban Drainage, 7-12 September 2014. Sarawak, Malaysia.

Muntohar, A.S. (2008). Proposal Ambang Hujan untuk Peringatan Dini Tanah Longsor, Seminar/ workshop "Application Research for Disaster and Humanitarian", 19 Desember 2009, University Club UGM

National Space Development of Japan (2001). TRMM Data Users Handbooks, National Space Development Agency of Japan, https://www.eorc.jaxa.jp/TRMM/document/tex t/handbook_e.pdf

Paimin, Sukresno, \& Pramono, I.B. (2009). Teknik Mitigasi Banjir dan Tanah Longsor. Tropenbos International Indonesia Programme, Balikpapan, ISBN 978-979-3145-46-4

Parwati, Suwarsono, Yulianto, F., \& Suprapto, T. (2008). Penentuan Nilai Ambang Batas Untuk Potensi Rawan Banjir Dari Data MTSAT Dan QMORPH (Studi Kasus: Banjir Bengawan Solo 2007), Jurnal Penginderaan Jauh Vol. 5, 2008: 5663

Peres D. J. \& Cancelliere A. (2013). Defining rainfall thresholds for early warning of rainfall-triggered landslides: The case of North-East Sicily. Landslide Science and Practice: Global Environmental Change, vol. 4:257-263

Peres D. J., Cancelliere A., Greco R., \& Thom A. Bogaard T. A., (2017), Influence of uncertain identification of triggering rainfall on the assessment of landslide early warning thresholds. Nat. Hazards Earth Syst. Sci., 18: 633-646 https://doi.org/10.5194/nhess-18-633

Satya, G., Andriawan, A.H., Ridho'i, A., \& Seputro, H., (2014), Intensitas Curah Hujan Memicu Tanah Longsor Dangkal di Desa Wonodadi Kulon, Jurnal Pengabdian LPPM Untag Surabaya, Vol.1(1):6571.

Sipayung, S.B., Cholianawati, N., Susanti I., Soni, A.R. \& Maryadi, E., (2014), Pengembangan Model Persamaan Empiris dalam Memprediksi Terjadinya Longsor di DAS Citarum, Jurnal Sains Dirgantara Vol. 12 (1). LAPAN Jakarta 